\title{
First molecular characterization of poxviruses in cattle, sheep, and goats in Botswana
}

\author{
Boitumelo Magret Modise ${ }^{1^{*}}\left(\mathbb{0}\right.$, Tirumala Bharani Kumar Settypalli ${ }^{2}$, Tebogo Kgotlele ${ }^{1}$, Dingrong Xue ${ }^{2,3}$, \\ Kebonyemodisa Ntesang ${ }^{1}$, Kago Kumile ${ }^{1}$, Ivancho Naletoski ${ }^{2}$ John Frederick Nyange ${ }^{1}$, Carter Thanda ${ }^{1}$, \\ Kenny Nametso Macheng ${ }^{1}$, Chandapiwa Marobela-Raborokgwe ${ }^{1}$, Gerrit Johannes Viljoen², \\ Giovanni Cattoli² and Charles Euloge Lamien²
}

\begin{abstract}
Background: Poxviruses within the Capripoxvirus, Orthopoxvirus, and Parapoxvirus genera can infect livestock, with the two former having zoonotic importance. In addition, they induce similar clinical symptoms in common host species, creating a challenge for diagnosis. Although endemic in the country, poxvirus infections of small ruminants and cattle have received little attention in Botswana, with no prior use of molecular tools to diagnose and characterize the pathogens.

Methods: A high-resolution melting (HRM) assay was used to detect and differentiate poxviruses in skin biopsy and skin scab samples from four cattle, one sheep, and one goat. Molecular characterization of capripoxviruses and parapoxviruses was undertaken by sequence analysis of RPO30 and GPCR genes.
\end{abstract}

Results: The HRM assay revealed lumpy skin disease virus (LSDV) in three cattle samples, pseudocowpox virus (PCPV) in one cattle sample, and orf virus (ORFV) in one goat and one sheep sample. The phylogenetic analyses, based on the RPO30 and GPCR multiple sequence alignments showed that the LSDV sequences of Botswana were similar to common LSDV field isolates encountered in Africa, Asia, and Europe. The Botswana PCPV presented unique features and clustered between camel and cattle PCPV isolates. The Botswana ORFV sequence isolated from goat differed from the ORFV sequence isolated from sheep.

Conclusions: This study is the first report on the genetic characterization of poxvirus diseases circulating in cattle, goats, and sheep in Botswana. It shows the importance of molecular methods to differentially diagnose poxvirus diseases of ruminants.

Keywords: Lumpy skin disease virus, Pseudocowpox virus, Orf virus, RPO30, GPCR, B2L gene, Botswana

*Correspondence: boikensmod@gmail.com

1 Botswana National Veterinary Laboratory, Private Bag 0035, Gaborone, Botswana

Full list of author information is available at the end of the article

\begin{abstract}
Background
Poxviruses exist throughout the world and are responsible for several economically significant zoonotic diseases affecting humans, wildlife, farming animals, and domestic animals $[1,2]$. Generally, poxviruses are epitheliotropic and may cause localized cutaneous lesions or generalized lesions of skin, organs and tissues (respiratory and digestive tract mucosa, lungs and kidney). Skin
\end{abstract} original author(s) and the source, provide a link to the Creative Commons licence, and indicate if changes were made. The images or other third party material in this article are included in the article's Creative Commons licence, unless indicated otherwise in a credit line to the material. If material is not included in the article's Creative Commons licence and your intended use is not permitted by statutory regulation or exceeds the permitted use, you will need to obtain permission directly from the copyright holder. To view a copy of this licence, visit http://creativecommons.org/licenses/by/4.0/. The Creative Commons Public Domain Dedication waiver (http://creativeco mmons.org/publicdomain/zero/1.0/) applies to the data made available in this article, unless otherwise stated in a credit line to the data. 
lesions can be clinically misdiagnosed as other cutaneous diseases. Economically, poxvirus diseases cause losses due to damage to the skin, decreased milk and meat production and trade restrictions in addition to morbidity and mortality $[3,4]$.

Poxviruses are complex, linear, enveloped, doublestranded DNA viruses with large genomes of 130-360 kb in length $[5,6]$. They belong to the Poxviridae family, which is divided into two subfamilies: Entomopoxvirinae, which infect invertebtates, and Chordopoxvirinae, which infect vertebrates [7]. The Chordopoxvirinae subfamily comprises 18 genera: Orthopoxvirus, Parapoxvirus, Avipoxvirus, Capripoxvirus, Leporipoxvirus, Suipoxvirus, Molluscipoxvirus, Cervidpoxvirus, Crocodylidpoxvirus, Yatapoxvirus, Centapoxvirus, Macropopoxvirus, Mustelpoxvirus, Oryzopoxvirus, Pteropopoxvirus, Salmonpoxvirus, Sciuripoxvirus and Vespertilionpoxvirus [8].

Among the Chordopoxvirus subfamily, are genera that affect livestock ruminants, some of which are capable of infecting the same animal species creating a challenge for clinical diagnosis. They include Capripoxvirus which is comprised of goatpox virus (GTPV), sheeppox virus (SPPV) and LSDV and Parapoxvirus, which includes ORFV, PCPV and bovine papular stomatitis virus (BPSV). Poxviruses can be transmitted through small abrasions of the skin (e.g.,ORFV), directly or indirectly from contaminated aerosols in the environment through the respiratory tract (e.g., SPPV and GTPV), and potential mechanical transmission by biting arthropods (e.g., LSDV and SPPV) [9-12].

In Botswana, poxvirus diseases in ruminants have received little attention, with no further characterization methods performed. The first publication on poxvirus diseases in Botswana was on ORFV in goats [13], without molecular characterization of the virus. Lumpy skin disease was first observed in 1943 following an outbreak in Ngamiland in northern Botswana. Since then, the disease has spread to most districts in the country [14]. In Botswana, LSD is controlled through vaccination with live attenuated vaccines; LSDV Neethling strain (Onderstepoort Biological Products; OBP, South Africa) and attenuated South African LSDV field isolate (Lumpyvax, MSD Animal Health-Intervet, South Africa). Even though LSD has been endemic and widespread in Botswana for many years, there is no genetic information available on LSDVs circulating in Botswana.

This study describes the clinical presentation, molecular detection, and molecular characterization of poxvirus diseases from clinical samples. We report the first confirmed case of pseudocowpox in Botswana, and the first molecular characterization of LSDV, ORVF, and PCPV in the country.

\section{Methods}

Study areas and sample collection

Six samples (three skin biopsies, one skin crust, one lip skin scab as well as one wart) from cattle, sheep and goat from Chobe, Central, Kweneng and Southern districts (Table 1 and Fig. 1) were used in this study. Chobe district in Northern Botswana has a high density of wildlife that regularly interact with livestock. The Central, Southern and Kweneng districts have a low density of wildlife and minimal to no contact with livestock.

Samples were submitted by field personnel to the Botswana National Veterinary Laboratory (BNVL) for routine testing. Initially, one sample from 2010, one from

Table 1 Information on the samples and animals from which specimens were collected for this study

\begin{tabular}{|c|c|c|c|c|c|c|c|c|c|}
\hline Sample ID & District & Sub-district & $\begin{array}{l}\text { Crush } \\
\text { (Countrside/ } \\
\text { urban) }\end{array}$ & $\begin{array}{l}\text { Year samples } \\
\text { received }\end{array}$ & & Age & Gender & Breed & $\begin{array}{l}\text { Type of } \\
\text { samples }\end{array}$ \\
\hline BOT_BOV/2010/6389 & Central & Mahalapye & $\begin{array}{l}\text { Tobela (Peri } \\
\text { urban) }\end{array}$ & 2010 & Cattle & Adult & F & Sharolin & Skin crust \\
\hline BOT_BOV/2016/172 & Chobe & $\begin{array}{l}\text { Kasane/ } \\
\text { Kavimba }\end{array}$ & $\begin{array}{l}\text { Maruza } \\
\text { (Country- } \\
\text { side) }\end{array}$ & 2016 & Cattle & $\begin{array}{l}\text { Information } \\
\text { not avail- } \\
\text { able }\end{array}$ & $\begin{array}{l}\text { Information } \\
\text { not avail- } \\
\text { able }\end{array}$ & Local Tswana & Skin biopsy \\
\hline BOT_OV/2017/158 & Southern & Jwaneng & $\begin{array}{l}\text { Sekwele } \\
\text { (Country- } \\
\text { side) }\end{array}$ & 2017 & Sheep & $\begin{array}{l}\text { Information } \\
\text { not avail- } \\
\text { able }\end{array}$ & $\begin{array}{l}\text { Information } \\
\text { not avail- } \\
\text { able }\end{array}$ & Dorper & Lip skin scab \\
\hline BOT_BOV/2017/1657 & Kweneng & Molepolole & $\begin{array}{l}\text { Prison Farm } \\
\quad \text { (Peri urban) }\end{array}$ & 2017 & Cattle & Adult & $\mathrm{F}$ & Brown swiss & Skin biopsy \\
\hline BOT_BOV/2019/246 & Central & Mahalapye & $\begin{array}{l}\text { Information } \\
\text { not avail- } \\
\text { able }\end{array}$ & 2019 & Cattle & $\begin{array}{l}\text { Information } \\
\text { not avail- } \\
\text { able }\end{array}$ & $\begin{array}{l}\text { Information } \\
\text { not avail- } \\
\text { able }\end{array}$ & $\begin{array}{l}\text { Information } \\
\text { not avail- } \\
\text { able }\end{array}$ & Skin biopsy \\
\hline $\begin{array}{l}\text { BOT_}_{-} \\
\text {CAP/2019/7419/74 }\end{array}$ & Chobe & Kasane & $\begin{array}{l}\text { Kachikau } \\
\text { (Country- } \\
\text { side) }\end{array}$ & 2019 & Goat & 1 year & $\mathrm{F}$ & Local Tswana & $\begin{array}{l}\text { Udder with } \\
\text { warts }\end{array}$ \\
\hline
\end{tabular}




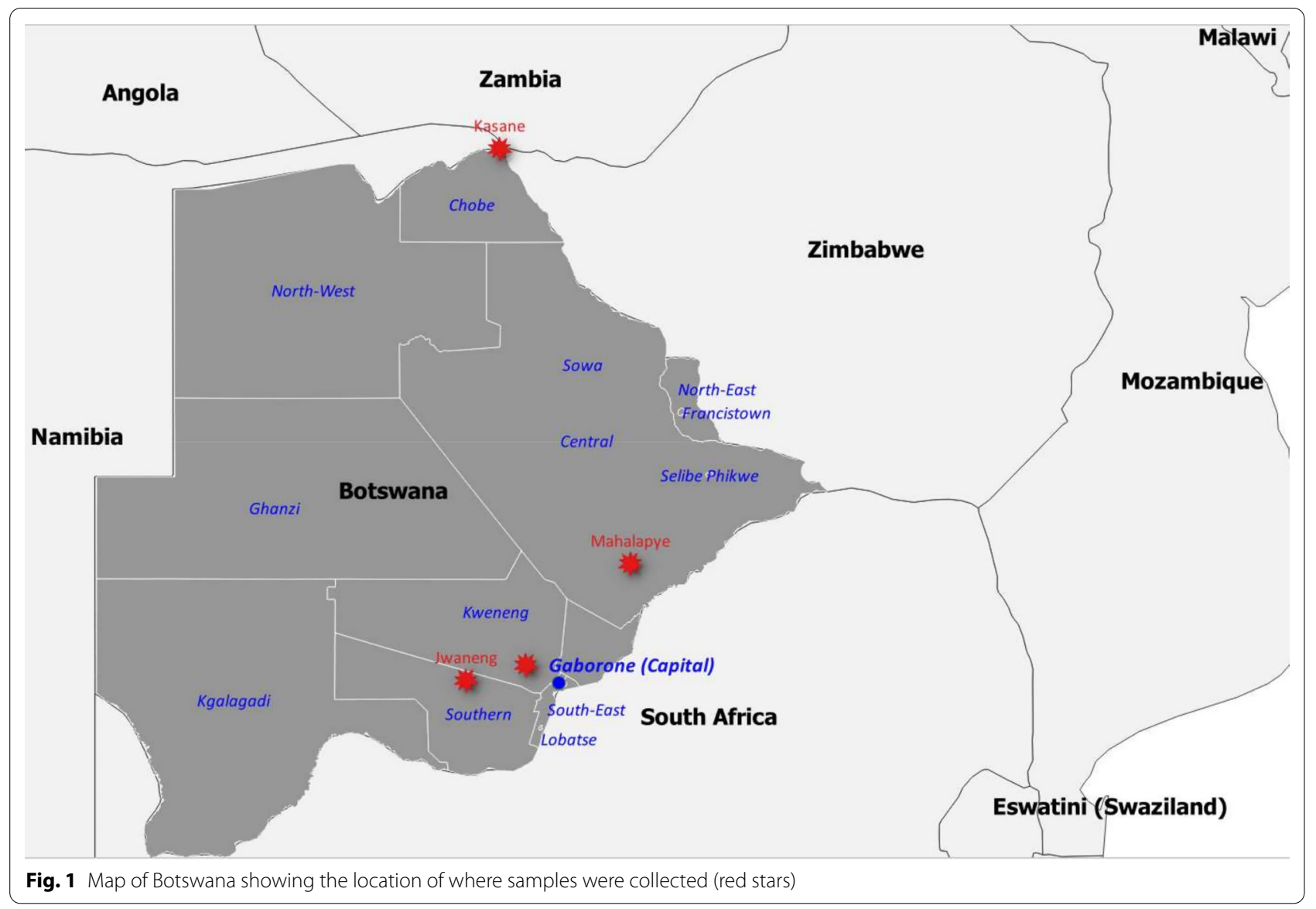

2016 and two from 2017 were tested by histopathological examination and the findings were suggestive of poxvirus infections (Table 3). In 2019, the same four samples and two additional samples from 2019 suspected of poxvirus infections were tested using a recently developed High Resolution Melting (HRM) assay for the simultaneous detection and differentiation of eight poxviruses of medical and veterinary importance, to confirm the poxvirus infections.

Epidemiological information including clinical signs and attempted clinical diagnosis were collected from original sample submission forms that accompanied the samples submitted to BNVL.

\section{Sample preparation and DNA extraction}

The samples were cut with a scalpel blade into small pieces and homogenized $(10 \% \mathrm{w} / \mathrm{v})$ in sterile phosphate buffered saline (PBS), then centrifuged at $2500 \mathrm{rpm}$ for $10 \mathrm{~min}$ to collect the supernatant. DNA was extracted from $200 \mu \mathrm{l}$ of the supernatant using DNeasy Blood and Tissue kit (Qiagen) following the manufacturer's instructions. The DNA was eluted in $80 \mu$ l elution buffer, then kept at $-20^{\circ} \mathrm{C}$ until further use.

\section{Molecular detection and genotyping}

The extracted DNA was tested using an HRM multiplex real-time assay for the simultaneous detection and differentiation of eight poxviruses of medical and veterinary importance [15]. The assay is based on high-resolution melting curve analysis of PCR amplicons produced using genus specific primer pairs and double stranded DNA binding dye, and exploits the differences in fragment size and GC content for discrimination. The method generates three well separated melting regions for each genus (Orthopoxvirus, Capripoxvirus, and Parapoxvirus) and provides additional genotyping of the viruses within each of the three genera (cowpox virus and camelpox virus in the Orthopoxvirus genus; GTPV, SPPV, and LSDV in the Capripoxvirus genus; ORFV, PCPV, and BPSV in the Parapoxvirus genus).

The PCR was set up in a $20 \mu \mathrm{l}$ reaction volume containing $1 \times$ SsoFast $^{\mathrm{TM}}$ EvaGreen $^{\circledR}$ Supermix (Bio-Rad), equal concentration $(200 \mathrm{nM})$ of each of the forward and reverse primers (Table 2), and $2 \mu$ of sample DNA. Each run included positive control plasmids representing each of the eight pathogens, and a negative control comprising nuclease-free water. The positive control plasmids 
used were Capripoxviruses (GTPV-Denizli, SPPV-Denizli, and LSDV-Ismalia), Orthopoxviruses (CMLVHadow/01/2012 and CPXV-72/93), and parapoxviruses (ORFV- DZ C-1, PCPV- 2200/12 and BPSV- Stamm M1) provided by IAEA. The PCR reactions and melting curve analysis were performed on the CFX96 Touch Real-Time PCR Detection System (Bio-Rad Laboratories), as previously described with slight modifications [15]. Briefly, an initial denaturation step at $95{ }^{\circ} \mathrm{C}$ for $4 \mathrm{~min}$, followed by 40 cycles at $95^{\circ} \mathrm{C}$ for $1 \mathrm{~s}, 59^{\circ} \mathrm{C}$ for $5 \mathrm{~s}$ and $70{ }^{\circ} \mathrm{C}$ for $5 \mathrm{~s}$. The PCR products were then denatured at $95^{\circ} \mathrm{C}$ for $30 \mathrm{~s}$, cooled down at $65{ }^{\circ} \mathrm{C}$ for $60 \mathrm{~s}$, and melted from $65^{\circ} \mathrm{C}$ to $85^{\circ} \mathrm{C}$ with an increment of $0.2^{\circ} \mathrm{C}$ every ten seconds and a continuous data acquisition. Data was analyzed using the CFX Maestro Software (Bio-Rad) and the Precision Melt Analysis Software (Bio-Rad).

\section{Sequencing}

The G-protein-coupled chemokine receptor (GPCR) [16], and the $30 \mathrm{kDa}$ DNA-dependent RNA polymerase subunit (RPO30) [17] genes of the Capripoxviruses were amplified using primers [18] in Table 2 . The PCR reaction was performed in a reaction volume of $20 \mu \mathrm{l}$ containing $500 \mathrm{nM}$ of each of the forward and reverse primers, $0.2 \mathrm{mM}$ of dNTPs, $1 \times$ buffer (Qiagen), $2.5 \mathrm{U}$ of Taq DNA polymerase (Qiagen), and $2 \mu \mathrm{l}$ template DNA. The amplification consisted of an initial denaturation at $95^{\circ} \mathrm{C}$ for 4 min followed by 35 cycles of $95^{\circ} \mathrm{C}$ for $40 \mathrm{~s}, 55^{\circ} \mathrm{C}$ for $\mathrm{RPO}$ and $56^{\circ} \mathrm{C}$ for GPCR for $30 \mathrm{~s}$, and $72{ }^{\circ} \mathrm{C}$ for $1 \mathrm{~min}$, and a final extension step at $72{ }^{\circ} \mathrm{C}$ for $7 \mathrm{~min}$.
For the Parapoxviruses, the partial B2L gene was amplified by PCR in a reaction volume of $25 \mu \mathrm{l}$ containing $500 \mathrm{nM}$ of each of the primers [19] in Table 2, two mM dNTPs, 1X PCR Buffer (Qiagen), 2.5 U Taq polymerase (Qiagen) and five $\mu \mathrm{l}$ template DNA. The cycling conditions were: initial denaturation at $95^{\circ} \mathrm{C}$ for $5 \mathrm{~min}$, followed by 35 cycles at $95^{\circ} \mathrm{C}$ for $50 \mathrm{~s}, 52^{\circ} \mathrm{C}$ for $60 \mathrm{~s}$ and $72{ }^{\circ} \mathrm{C}$ for $90 \mathrm{~s}$, and a final extension at $72^{\circ} \mathrm{C}$ for $7 \mathrm{~min}$.

All PCR products were separated by electrophoresis on a $1.5 \%$ agarose gel at $100 \mathrm{~V}$ for $1 \mathrm{~h}$. The positive PCR products were purified using the Wizard SV Gel and PCR clean-up system kit (Promega) according to the manufacturer's instructions, then sequenced commercially by LGC Genomics (Germany). The sequences were edited and assembled using Vector NTI Advance ${ }^{\mathrm{TM}} 11.5$ software (Invitrogen, Carlsbad, CA, USA). All sequences were submitted to GenBank.

\section{Phylogenetic analysis}

For phylogenetic reconstructions of the RPO30, GPCR, and $\mathrm{B} 2 \mathrm{~L}$ gene trees, multiple sequence alignments of the nucleotides sequences were performed separately for each gene using the muscle algorithm and the codon option implemented in MEGA7 [20]. Additional sequences of the RPO30 and GPCR gene for CaPVs (LSDVs, GTPVs, and SPPVs) and the B2L gene for parapoxviruses (ORFV, PCPV, and BPSV), were retrieved from GenBank and included for comparative analyses.

The sequence alignment FASTA file was converted into a Nexus format file using Seaview programme version 4.7

Table 2 Primers used in this study for the HRM assay and sequencing

\begin{tabular}{|c|c|c|c|c|}
\hline Method & Primer name & Primer sequence & Amplicon size & Target and references \\
\hline \multirow[t]{6}{*}{ HRM } & CaPV-HRM-For & TCCTGGCATTTTAAGTAATGGT & 100 & Capripoxviruses [15] \\
\hline & CaPV-HRM-Rev & GTCAGATATAAACCCGGCAAGTG & & \\
\hline & PPV-HRM-For & TCGAAGATCTTGTCCAGGAAG & 112 & Parapoxviruses [15] \\
\hline & PPV-HRM-Rev & CCGAGAAGATCAACGAGGTC & & \\
\hline & OPV-HRM-For & AGGACTAGCCGCGGTAACTTT & 56 & Orthopoxviruses [15] \\
\hline & OPV-HRM-Rev & ACAAGATAGAAGCGATGGATACTT & & \\
\hline \multirow[t]{12}{*}{ Sequencing } & CpGPCR-OL1F & TGAAAAATTAATCCATTCTTCTAAACA & 617 & Capripoxviruses [18] \\
\hline & CpGPCR-OL1R & TCATGTATTTTATAACGATAATGCAAA & & \\
\hline & CpGPCR-OL2F & TTAGCGGTATAATCATTCCAAATA & 603 & \\
\hline & CpGPCR-OL2R & GCGATGATTATGATGATTATGAAGTG & & \\
\hline & CpGPCR-OL3F & CACAATTATATTTCCAAATAATCCAA & 684 & \\
\hline & CpGPCR-OL3R & TGTACATGTGTAATTTTAATGTTCGTA & & \\
\hline & CpRPO30-OL1F & CAGCTGTTTGTTTACATTTGATTTTT & 554 & \\
\hline & CpRPO30-OL1R & TCGTATAGAAACAAGCCTTTAATAGA & & \\
\hline & CpRPO30-OL2F & TTTGAACACATTTTATTCCAAAAAG & 520 & \\
\hline & CpRPO30-OL2R & AACCTACATGCATAAACAGAAGC & & \\
\hline & ORFV-B2Lf-For & GACCTTCCGCGCTTTAATTT & 1210 & Parapoxviruses [19] \\
\hline & ORFV-B2Lf-Rev & CCCGCCTGCTAAAAGACT & & \\
\hline
\end{tabular}


[21]. The Bayesian phylogenetic inference was performed with BEAST. First, the BEAUti module was used to generate BEAST files using the TN93+ G nucleotide substitution and a UPGMA starting tree. The Markov Chain Monte Carlo method was run with BEAST for 10,000,000 generations with a sample taken each 10,000 generations. The TRACER program was used to inspect the $\log$ files and determine the optimum number of burn-in based on the Effective Sample Sizes (ESS > 200). TreeAnnotator was used to generate the Maximum Clade Credibility (MCC) after discarding the $2 \%$ burn-in. The tree was visualized with the associated meta-data using the ggtree package in $\mathrm{R}$ version 3.5.2 [22]. Additionally, for the GPCR tree, the multiple sequence alignment file of the nucleotide sequences was imported and a slice of the alignment, between positions 80 and 120, was visualized together with the tree [22].

\section{Results}

\section{Clinical diagnosis and molecular detection}

It appeared that most animals had lesions suggestive either of poxvirus infections, and sometimes, papillomavirus infections (Table 3).

As summarised in Table 3, PCPV DNA was detected in one out of four cattle samples (BOT_BOV/2010/6389) and LSDV DNA in three out of four cattle samples (BOT_BOV/2016/172, BOT_BOV/2017/1657, and BOT_BOV/2019/246) using the HRM real-time PCR assay. ORFV DNA was detected in both sheep and goat samples, respectively (BOT_OV/2017/158 and
BOT_CAP/2019/74), with Orthopoxvirus DNA absent in all samples. Figure 2 shows the melting peaks corresponding to PCPV, LSDV, and ORFV in the Botswana samples.

\section{Molecular characterization and phylogenetic analysis}

Two fragments for the RPO30 gene (554 bp and $520 \mathrm{bp}$ ) and three fragments for the GPCR gene $(617 \mathrm{bp}, 603 \mathrm{bp}$, and $684 \mathrm{bp}$ ) were successfully amplified and sequenced in all three LSDV positive samples (BOT_BOV/2016/172, BOT_BOV/2017/1657, and BOT_BOV/2019/246). Similarly, an approximately 1210 bp fragment of the B2L gene was amplified and sequenced in the remaining three samples that were positive for PCPV (BOT_ BOV/2010/6389) and ORFV (BOT_OV/2017/158, and BOT_CAP/2019/74). The complete RPO30 and GPCR genes and partial B2L gene sequences were submitted to GenBank database under accession numbers MW748471 to MW748479.

In both GPCR and RPO30 gene phylogenetic trees, all three cattle samples from Botswana (BOT_ BOV/2016/172, BOT_BOV/2017/1657, and BOT_ BOV/2019/246) clustered within the LSDV group (Figs. 3 and 4). For the GPCR gene, the LSDV group was further subdivided into two subgroups: the first subgroup included the LSDVs from Botswana, and field LSDVs from Europe, the Middle East and Africa, and LSDV KS1 derived vaccinal viruses. The second subgroup consisted of LSDV Neethling-like viruses, and the historical LSDV Haden 1959 from South Africa (Fig. 3).

Table 3 Summary of clinical signs, attempted clinical diagnosis and molecular findings of the different poxviruses

\begin{tabular}{|c|c|c|c|c|c|}
\hline Sample ID & $\begin{array}{l}\text { Case history (clinical } \\
\text { signs) }\end{array}$ & $\begin{array}{l}\text { Attempted clinical } \\
\text { diagnosis }\end{array}$ & $\begin{array}{l}\text { Histopathology } \\
\text { findings }\end{array}$ & Molecular findings & $\begin{array}{l}\text { Sequenced gene (s) } \\
\text { (Accession number) }\end{array}$ \\
\hline BOT_BOV/2010/6389 & $\begin{array}{l}\text { Recumbent, bleeding } \\
\text { wounds on the udder, } \\
\text { mouth, anus, and legs }\end{array}$ & Papillomatosis & $\begin{array}{l}\text { Sample not suitable for } \\
\text { testing }\end{array}$ & PCPV positive & B2L (MW748473) \\
\hline BOT_BOV/2016/172 & $\begin{array}{l}\text { Cattle developing skin } \\
\text { nodules all over the } \\
\text { body }\end{array}$ & LSD & $\begin{array}{l}\text { Proliferative dermatitis } \\
\text { Suggestive of LSD }\end{array}$ & LSDV positive & $\begin{array}{l}\text { RPO30 (MW748474); } \\
\text { GPCR (MW748477) }\end{array}$ \\
\hline BOT_OV/2017/158 & $\begin{array}{l}\text { Lesions on and around } \\
\text { mouth and buccal } \\
\text { cavity }\end{array}$ & Orf & $\begin{array}{l}\text { Referred to laboratory } \\
\text { outside Botswana } \\
\text { but results were not } \\
\text { received }\end{array}$ & ORFV positive & B2L (MW748471) \\
\hline BOT_BOV/2017/1657 & $\begin{array}{l}\text { Cow with skin bumps } \\
\text { and lameness }\end{array}$ & LSD & $\begin{array}{l}\text { Proliferative dermatitis } \\
\text { with collegenolysis } \\
\text { suggestive of LSD }\end{array}$ & LSDV positive & $\begin{array}{l}\text { RPO30 (MW748475); } \\
\text { GPCR (MW748478) }\end{array}$ \\
\hline BOT_BOV/2019/246 & $\begin{array}{l}\text { Lesions on the skin, nasal } \\
\text { discharge, and lacrima- } \\
\text { tion }\end{array}$ & LSD & Test not done & LSDV positive & $\begin{array}{l}\text { RPO30 (MW748476); } \\
\text { GPCR (MW748479) }\end{array}$ \\
\hline BOT_CAP/2019/74 & $\begin{array}{l}\text { Udder of a dead goat } \\
\text { with papilloma warts } \\
\text { like/ orf infection on } \\
\text { udder }\end{array}$ & Orf, Papilloma warts & Test not done & ORFV positive & B2L (MW748472) \\
\hline
\end{tabular}




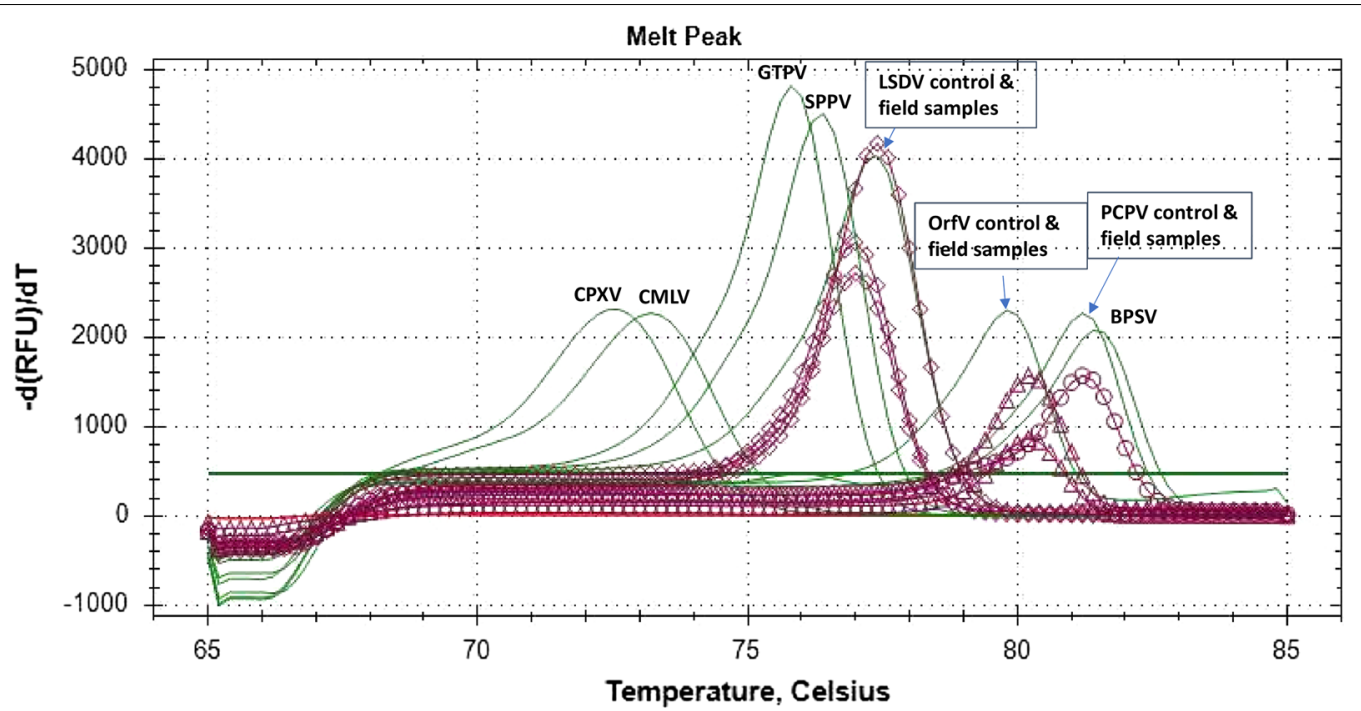

Fig. 2 HRM detection of poxvirus diseases in cattle, goats, and sheep samples from Botswana. The positive control for each of the eight poxviruses displayed a unique melting peak, shown in green color. One cattle and three cattle samples clustering with PCPV and LSDV, respectively, and one goat and one sheep samples clustering with ORFV are shown in purple colour

The multiple sequence alignments of the GPCR gene showed that all the Botswana LSDVs had sequences identical to each other, and presented a 12-nucleotide deletion found in common field LSDV isolates (Fig. 3).

For the RPO30 gene (Fig. 4), LSDV isolates produced 3 sub-groups: the first one consisted of the Botswana LSDVs and common field LSDVs encountered in Africa, the Middle East and Europe. The second subgroup contained LSDV KS1-like viruses and LSDV NI-2490, while the third consisted of LSDV Neethling like viruses and the historical LSDV Haden 1959 (Fig. 4).

The RPO30 gene sequences were identical for all the Botswana LSDVs and identical to common field isolates, but different from the the vaccinal strains derived from KS1 and Neethling viruses. The Botswana isolates differed from LSDVs from Sudan, (GU119938) and (GU119944), by a single non synomymous nucleotide difference leading to amino acid substitutions at one position $\left(\mathrm{T}^{14} \rightarrow \mathrm{N}\right.$ and $\left.\mathrm{D}^{102} \rightarrow \mathrm{G}\right)$ respectively.

On the phylogenetic tree of the $\mathrm{B} 2 \mathrm{~L}$ gene, the sequence of sample BOT_BOV/2010/6389 clustered with PCPVs (Fig. 5). Within the PCPV group, BOT_BOV/2010/6389 clutered between the B2L sequences of camel isolates and those of cattle/reindeer isolates. The $\mathrm{B} 2 \mathrm{~L}$ sequences of the two samples BOT_OV/2017/158 and BOT_ CAP/2019/74, collected from small ruminants, clustered within the ORFV group (Fig. 5).

The BLAST results showed that the nucleotide identities of the Botswana PCPV, BOT_BOV/2010/6389, against published parapoxviruses ranged from 98.63\%98.97\% with the highest identity (98.97\%) to PCPV strains strain 3/07 (KF478804) isolated from cattle in Germany, and strain VR634 (GQ329670) collected from man infected by cattle in New Zealand.

The B2L sequence of ORFV BOT_CAP/2019/74 was $100 \%$ identical to that of strain OV-SA00 (AY386264) isolated from a goat in the USA. The multiple sequence alignments of the $\mathrm{B} 2 \mathrm{~L}$ gene revealed 24 nucleotide changes between the B2L gene of BOT_CAP/2019/74 and BOT_OV/2017/158.

\section{Discussion}

This study presents the first confirmed case of PCPV in Botswana and the first molecular characterization of poxviruses affecting sheep, goats and cattle in the country from animals presenting clinical lesions consistent with poxvirus infections. The DNA of LSDV (3 samples), PCPV (1 sample), and ORFV (2 samples) were detected in clinical samples from 2010, 2016, 2017, and two recent samples from 2019 using an HRM assay for the differential diagnosis of poxvirus infections [15]. It is worth noting that the status of the 2010 sample was previously undetermined, until the availability of this HRM assay which showed the presence of PCPV. Hence, the HRM assay has enabled the correct identification of LSDV and PCPV in cattle and ORFV in small ruminants in a single convenient assay [15].

The attempted clinical diagnosis of the poxvirus diseases were mostly consistent with the results of the HRM assay for LSDV and ORFV. The LSD suspected cattle had typical clinical signs that included skin nodules/ 


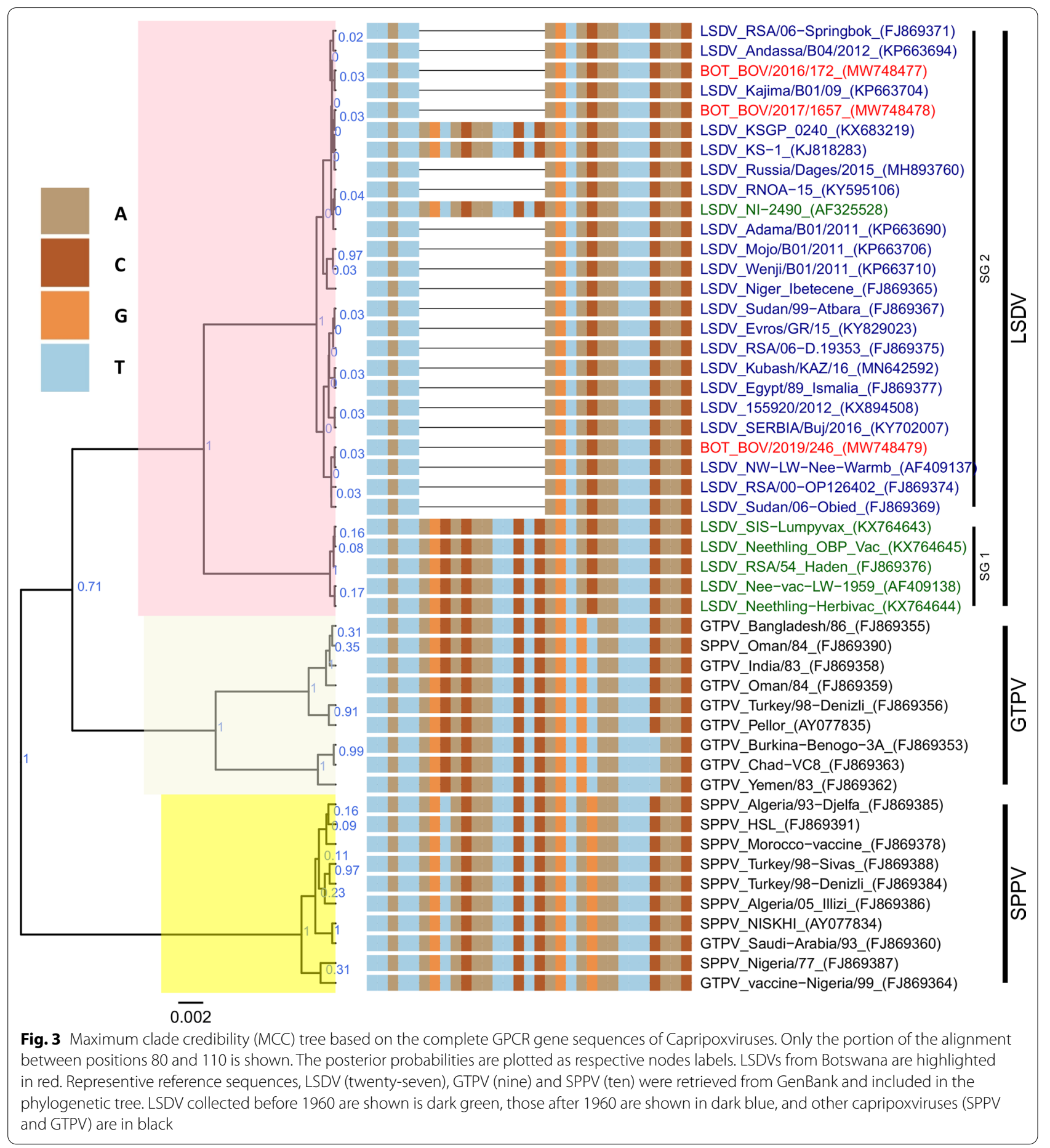

bumps/lesions [23, 24] and orf suspected small ruminants had papilloma warts on the udder and/ or lesions on and around the mouth and buccal cavity as previously described $[25,26]$. However, in this study, the lesions decribed for the PCPV positive animal were mostly suggestive for papillomavirus infections, though, the lesions on the udder of cattle are also common in pseudocowpox infections [27, 28].

For all samples, the sequencing data was in full agreement with the HRM data. The RPO30 and GPCR gene sequences of the Botswana LSDV samples were identical even through they were collected from three 


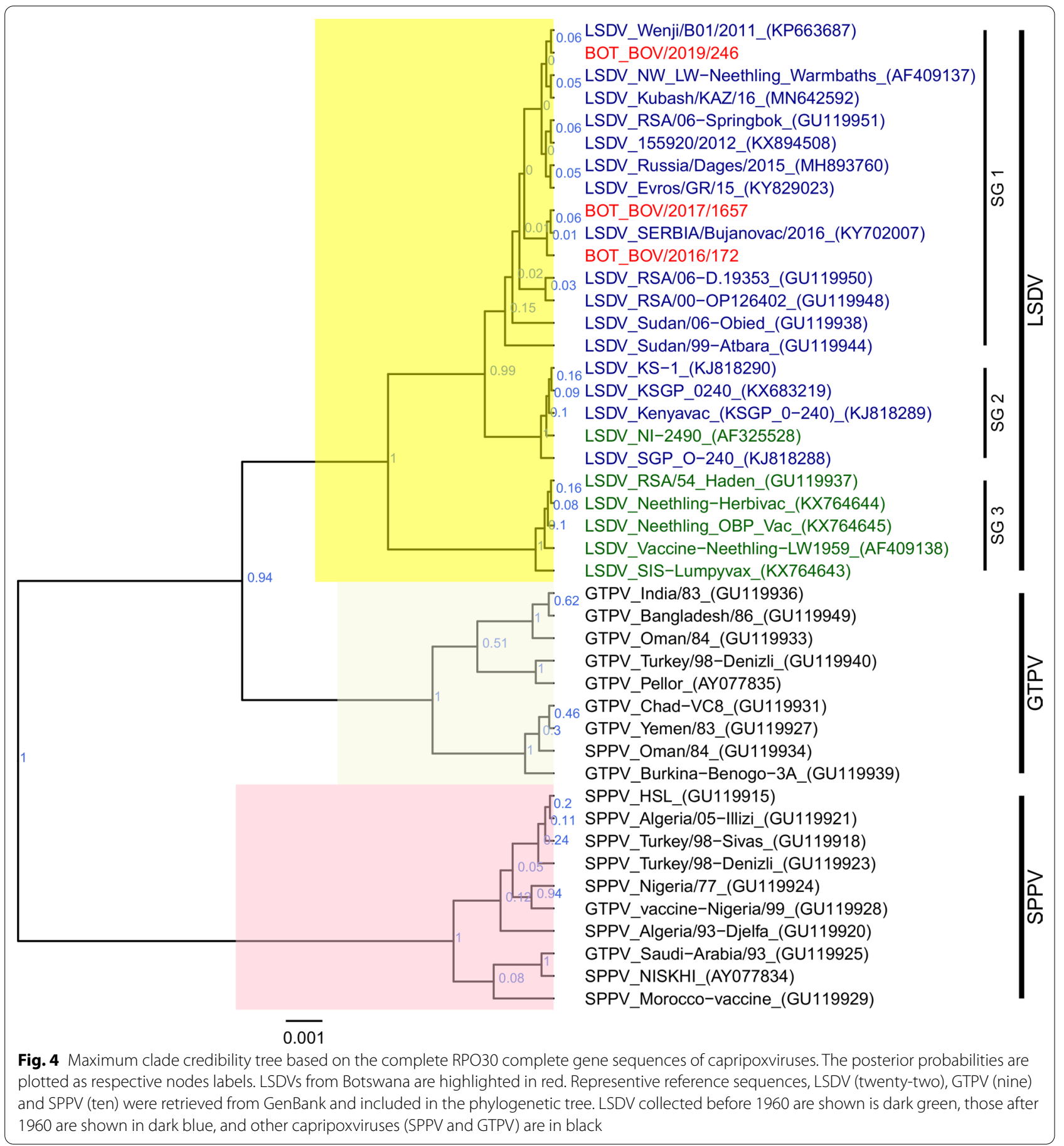

different years, 2016, 2017 and 2019, and from 3 different geographic locations (Central, Chobe and Kweneng districts). This suggests that the virus is well conserved and that the same strain is responsible for all cases.

Moreover, the Botswana LSDV sequences presented similar features to common field isolates of LSDV encountered in Africa, Europe and Asia, including the presence of the 12-nucleotide deletion in their GPCR gene $[16,18,29-31]$.

The existence of PCPV in cattle has been reported worldwide [32-35]. In Africa, the disease has recently been reported in Zambia [36] and now in Botswana (this study). Interestingly, the phylogenetic analysis revealed that the newly sequenced PCPV from Botswana was 


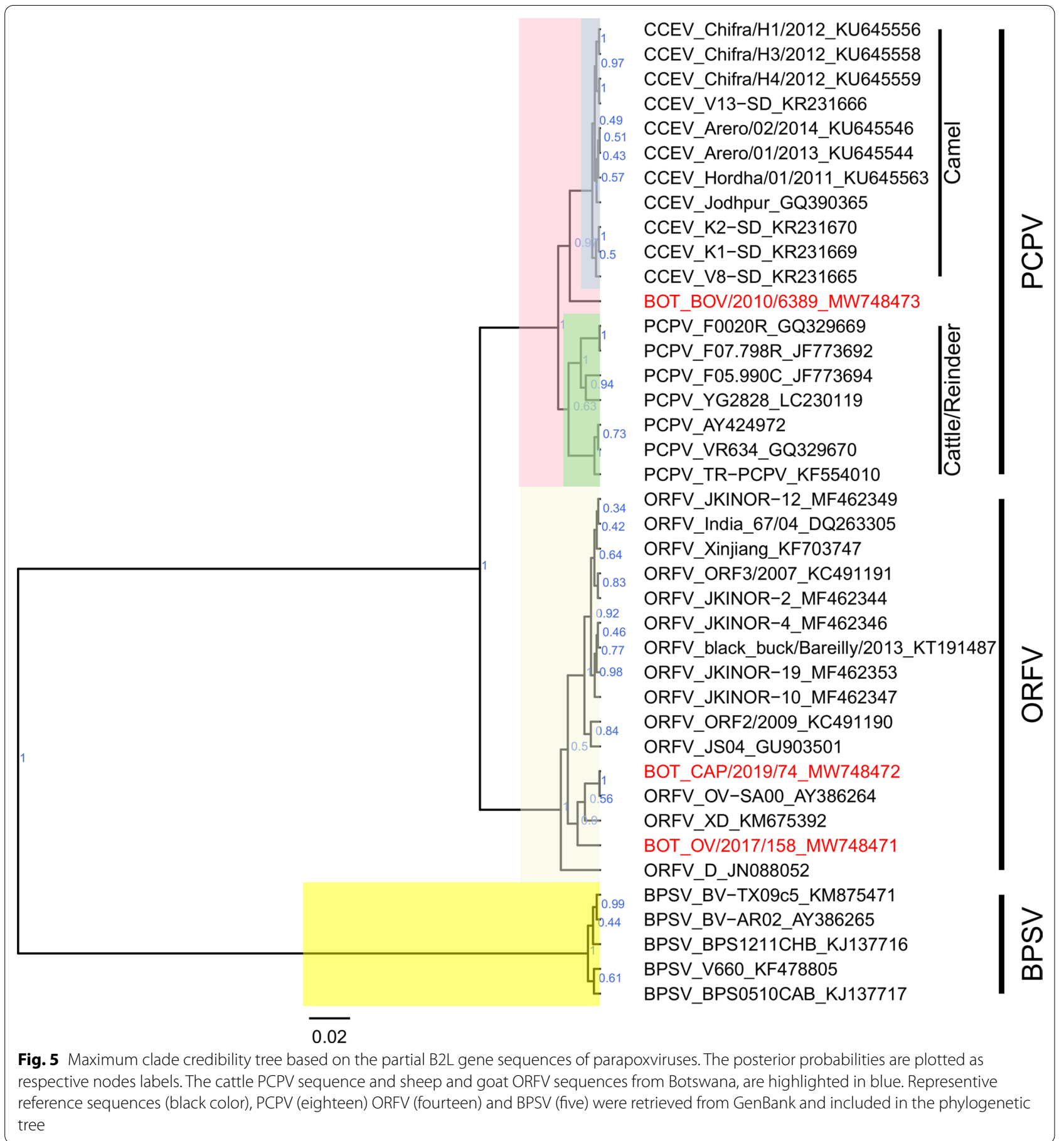

distinct from common cattle PCPVs encountered elsewhere, behaving like an intermediate isolate between cattle isolates of PCPV and camel isolates of PCPV (known as CCEV). This finding is uncommon, as most isolates recovered from cattle usually clustered with the cattle/ reindeer isolates. For instance, PCPVs that were recently reported in Zambia presented substantial sequence variation within the same herd and during the same outbreak events in 2017 and 2018, but were all clustering with the cattle isolates of PCPVs [36]. The unique genetic feature of the Botswana PCPV suggests that by the time the case was recorded in 2010, PCPV was already well established in the country. 
The path of introduction of the PCPV strain to Botswana is unknown and requires further investigation. Additional genetic analysis of the PCPV strain is also required to determine if it is genetically distinct enough to be classified as cattle,reindeer or camel variant of PCPV virus.

The phylogenetic tree based on the B2L gene sequence, and the scrutiny of the multiple sequence alignment showed that the sample collected in sheep in 2017 in northern Botswana differed from that of the sample collected in goat in 2019 in the southern part of the country, suggesting that at least two different strains of ORFV are circulating in the country.

The caprine ORFV B2L sequence was very similar to an ORFV OV-SA00 (AY386264) isolate collected from a goat in the USA in 2000. The ovine ORFV sequence differed from most ovine sequences, but displayed $99.6 \%$ amino acid similarity to isolate FJ-ZX (KC568400) collected from a goat in China in 2012.

\section{Conclusion}

This paper reports the first molecular detection and characterization of poxvirus diseases circulating in sheep, goat and cattle in Botswana. It shows the importance of molecular methods for the differential diagnosis of poxvirus diseases in ruminants (the presence of LSDV and PCPV in cattle and ORFV in small ruminants). Based on our findings, we recommend the HRM assay be used as a rapid screening and confirmatory tool for poxvirus infections during disease investigations and epidemiological studies. PCPV is a zoonotic disease that farmers in Botswana have limited information on. Publication of this information coupled with improved public health awareness campaigns to local farmers will provide the necessary information about pseudocowpox virus to educate future recognition of disease and timely reporting and treatment. Considering PCPV's risk of dissemination, strict hygiene measures should be applied to prevent transmission to humans when detected. Country-wide surveillance is recommended to determine the prevalence of LSDV and PCPV infections in cattle, ORFV in sheep and goats in Botswana, and to identify infection risks for other animals and humans. The correct identification of the etiologic agent of pox-like lesions in ruminants is essential to allow for proper pox disease management and control, and to improve veterinary interventions, including vaccination of non-infected surrounding herds in the case of LSD.

\footnotetext{
Abbreviations

BNVL: Botswana National Veterinary Laboratory; BPSV: Bovine papular stomatitis virus; DNA: Deoxyribonucleic acid; GTPV: Goatpox virus; HRM: High resolution melting; LSDV: Lumpy skin disease virus; MCC: Maximum Clade
}

Credibility; ORFV: Orf virus; PBS: Phosphate buffered saline; PCR: Polymerase chain reaction; PCPV: Pseudocowpox virus; SPPV: Sheeppox virus.

\section{Acknowledgements}

The authors would like to thank the Veterinary field personnel and the Disease Control Unit for collecting samples from the field and Dr. Jenna E. Achenbach (Battelle, VA, USA) for critically evaluating the manuscript and improving the writing.

\section{Authors' contributions}

Conceived and designed the study: BMM, and CEL. Performed the experiments: BMM, TBKS, TK, DX, KN, KK, JFN, CT. Analyzed the data: BMM, DX, CEL. Contributed reagents/materials/analysis tools: IN, GJV, GC, CEL. Wrote the paper: BMM. Supervised the study: KNM, CMR, GJV, GC, CEL. Edited the final manuscript:TBKS, JFN, CMR, GJV, GC, CEL. All authors read and approved the final manuscript.

\section{Funding}

This study was supported by VETLAB network initiative of the Joint FAO/IAEA Division, funded through the African Renaissance and International Cooperation fund of South Africa and the Peaceful Uses Initiatives (PUI) by Japan and the United States of America.

\section{Availability of data and materials}

DNA sequences generated and analyzed under the current study are available in GenBank under accession numbers MW748471, MW748472, and MW748473 (B2L gene), MW748474, MW748475, and MW748476 (RPO30 gene), MW748477, MW748478, and MW748479 (GPCR gene).

\section{Declarations}

Ethics approval and consent to participate

Samples used were for routine diagnosis at the Botswana National Veterinary Laboratory.

\section{Consent for publication}

The study was approved for publication by the Ministry of Agricultural Development and Food Security, Botswana.

\section{Competing interests}

The authors declared no conflicts of interest.

\section{Author details}

${ }^{1}$ Botswana National Veterinary Laboratory, Private Bag 0035, Gaborone, Botswana. ${ }^{2}$ Animal Production and Health Section, Animal Production and Health Laboratory, Joint FAO/IAEA Division of Nuclear Techniques in Food and Agriculture, Department of Nuclear Sciences and Applications, International Atomic Energy Agency, Vienna International Centre, PO Box 100, 1400 Vienna, Austria. ${ }^{3}$ Academy of National Food and Strategic Reserves Administration, Beijing, China.

Received: 13 April 2021 Accepted: 3 August 2021

Published online: 14 August 2021

\section{References}

1. Brettschneider H, Voster JH, Lane EP, Van Wilpe E, Biden P, Dalton DL, et al. Molecular detection of Yaba monkey tumour virus from a vervet monkey. J S Afr Vet Assoc. 2013;84(1):1-5.

2. Poxviridae. In: N. James MacLachlan EJD, editors. Fenner's Veterinary Virology. Fourth ed: Academic Press; 2011. p. 151-65. https://www. sciencedirect.com/science/article/pii/B9780123751584000079

3. Gambo P, Maguda A, Adole J, Dyek D, Ifende V, Bot C, et al. A survey of viral diseases of livestock characterized by skin lesions in Kanam Local Government Area of Plateau State. Nigeria Nig Vet J. 2018;39(3):250-62.

4. Babiuk S, Bowden TR, Boyle DB, Wallace DB, Kitching RP. Capripoxviruses: an emerging worldwide threat to sheep, goats and cattle. Transbound Emerg Dis. 2008;55(7):263-72. 
5. Stanford MM, McFadden G, Karupiah G, Chaudhri G. Immunopathogenesis of poxvirus infections: forecasting the impending storm. Immunol Cell Biol. 2007:85(2):93-102.

6. Essbauer S, Pfeffer M, Meyer H. Zoonotic poxviruses. Vet Microbiol. 2010;140(3-4):229-36.

7. Maclachlan NJ, Dubovi EJ. Fenner's veterinary virology. 4th ed. New York: Academic press; 2010

8. Lefkowitz EJ, Dempsey DM, Hendrickson RC, Orton RJ, Siddell SG, Smith DB. Virus taxonomy: the database of the International Committee on Taxonomy of Viruses (ICTV). Nucleic Acids Res. 2018;46(D1):D708-17.

9. Fleming SB, Wise LM, Mercer AA. Molecular genetic analysis of orf virus: a poxvirus that has adapted to skin. Viruses. 2015;7(3):1505-39.

10. Bowden TR, Babiuk SL, Parkyn GR, Copps JS, Boyle DB. Capripoxvirus tissue tropism and shedding: a quantitative study in experimentally infected sheep and goats. Virology. 2008;371 (2):380-93.

11. Sprygin A, Pestova Y, Wallace D, Tuppurainen E, Kononov A. Transmission of lumpy skin disease virus: a short review. Virus Res. 2019;269:197637.

12. Limon G, Gamawa AA, Ahmed Al, Lyons NA, Beard PM. Epidemiological characteristics and economic impact of lumpy skin disease, sheeppox and goatpox among subsistence farmers in northeast Nigeria. Front Vet Sci. 2020;7:8.

13. Baipoledi E, Nyange J, Hyera J. A severe case of contagious ecthyma in Tswana goats: case report. J S Afr Vet Assoc. 2002;73(2):86-7.

14. HANDISTATUS II Prototype. 2016. https://web.oie.int/hs2/report.asp. (Accessed 08 July 2021)].

15. Gelaye E, Mach L, Kolodziejek J, Grabherr R, Loitsch A, Achenbach JE, et al. A novel HRM assay for the simultaneous detection and differentiation of eight poxviruses of medical and veterinary importance. Sci Rep. 2017;7:42892.

16. Le Goff C, Lamien CE, Fakhfakh E, Chadeyras A, Aba-Adulugba E, Libeau G, et al. Capripoxvirus G-protein-coupled chemokine receptor: a host-range gene suitable for virus animal origin discrimination. J Gen Virol. 2009;90(Pt 8):1967-77.

17. Lamien CE, Le Goff C, Silber R, Wallace DB, Gulyaz V, Tuppurainen E, et al. Use of the Capripoxvirus homologue of Vaccinia virus $30 \mathrm{kDa}$ RNA polymerase subunit (RPO30) gene as a novel diagnostic and genotyping target: development of a classical PCR method to differentiate Goat poxvirus from Sheep poxvirus. Vet Microbiol. 2011;149(1-2):30-9.

18. Gelaye E, Belay A, Ayelet G, Jenberie S, Yami M, Loitsch A, et al. Capripox disease in Ethiopia: genetic differences between field isolates and vaccine strain, and implications for vaccination failure. Antiviral Res. 2015;119:28-35.

19. Gelaye E, Achenbach JE, Jenberie S, Ayelet G, Belay A, Yami M, et al. Molecular characterization of orf virus from sheep and goats in Ethiopia, 2008-2013. Virol J. 2016;13(1):1-12.

20. Kumar S, Stecher G, Tamura K. MEGA7: molecular evolutionary genetics analysis version 7.0 for bigger datasets. Mol Biol Evol. 2016;33(7):1870-4

21. Gouy M, Guindon S, Gascuel O. SeaView version 4: a multiplatform graphical user interface for sequence alignment and phylogenetic tree building. Mol Biol Evol. 2010;27(2):221-4.

22. Yu G, Smith DK, Zhu H, Guan Y, Lam TTY. ggtree: an $R$ package for visualization and annotation of phylogenetic trees with their covariates and other associated data. Methods Ecol Evol. 2017:8(1):28-36.
23. Tageldin MH, Wallace DB, Gerdes GH, Putterill JF, Greyling RR, Phosiwa MN, et al. Lumpy skin disease of cattle: an emerging problem in the Sultanate of Oman. Trop Anim Health Prod. 2014;46(1):241-6.

24. Leliso SA, Dawo F, Chibsa TR. Molecular Characterization of Lumpy Skin Disease Virus Isolates from Outbreak Cases in Cattle from Sawena District of Bale Zone, Oromia, Ethiopia. Veterinary Medicine International. 2021;2021.

25. Smith GW, Scherba G, Constable PD, Hsiao V, Behr MJ, Morin DE. Atypical parapoxvirus infection in sheep. J Vet Intern Med. 2002;16(3):287-92.

26. Nandi S, De UK, Chowdhury S. Current status of contagious ecthyma or orf disease in goat and sheep: a global perspective. Small Rumin Res. 2011;96(2-3):73-82

27. Büttner M, Rziha HJ. Parapoxviruses: from the lesion to the viral genome. J Vet Med. 2002:49(1):7-16.

28. Sant'Ana FJD, Leal FA, Rabelo RE, Vulcani VA, Moreira CA Jr, Cargnelutti JF, et al. Coinfection by Vaccinia virus and an Orf virus-like parapoxvirus in an outbreak of vesicular disease in dairy cows in midwestern Brazil. J Vet Diagn Invest. 2013;25(2):267-72.

29. Ochwo S, VanderWaal K, Ndekezi C, Nkamwesiga J, Munsey A, Witto SG, et al. Molecular detection and phylogenetic analysis of lumpy skin disease virus from outbreaks in Uganda 2017-2018. BMC Vet Res. 2020;16(1):1-10.

30. Sprygin A, Babin Y, Pestova Y, Kononova S, Wallace DB, Van Schalkwyk $A$, et al. Analysis and insights into recombination signals in lumpy skin disease virus recovered in the field. PLoS ONE. 2018;13(12):e0207480.

31. Agianniotaki El, Tasioudi KE, Chaintoutis SC, lliadou P, ManganaVougiouka O, Kirtzalidou A, et al. Lumpy skin disease outbreaks in Greece during 2015-16, implementation of emergency immunization and genetic differentiation between field isolates and vaccine virus strains. Vet Microbiol. 2017;201:78-84.

32. Ohtani A, Yokoyama A, Narushige H, Inoshima Y. First isolation and genetic characterization of pseudocowpox virus from cattle in Japan. Virol J. 2017;14(1):172.

33. Matsumoto H, Setoyama H, Matsuura Y, Ohtani A, Shimizu K, Okada A, et al. Sequential detection of pseudocowpox virus and bovine papular stomatitis virus in a same calf in Japan. J Vet Med Sci. 2019;81(3):440-3.

34. Cargnelutti JF, Flores MM, Teixeira FR, Weiblen R, Flores EF. An outbreak of pseudocowpox in fattening calves in southern Brazil. J Vet Diagn Invest. 2012;24(2):437-41.

35. Friederichs $\mathrm{S}$, Krebs $\mathrm{S}$, Blum $\mathrm{H}$, Wolf E, Lang $\mathrm{H}$, von Buttlar $\mathrm{H}$, et al. Comparative and retrospective molecular analysis of Parapoxvirus (PPV) isolates. Virus Res. 2014;181:11-21.

36. Ziba MW, Chitala C, Settypalli TBK, Mumba M, Cattoli G, Fandamu P, et al. First detection and molecular characterisation of pseudocowpox virus in a cattle herd in Zambia. Virol J. 2020;17(1):152.

\section{Publisher's Note}

Springer Nature remains neutral with regard to jurisdictional claims in published maps and institutional affiliations. 